\title{
Editorial
}

https://doi.org/10.11646/megataxa.6.1.1

http://zoobank.org/urn:1sid:zoobank.org:pub:01E47037-74BF-46F7-8B4E-D11C933F8091

\section{All genera of the world: an introduction to the inventory}

\author{
ZHI-QIANG ZHANG ${ }^{1,2}$ \\ ${ }^{1}$ Manaaki Whenua - Landcare Research, 231 Morrin Road, Auckland, New Zealand; \\ ”zhangz@landcareresearch.co.nz; @ ittps://orcid.org/0000-0003-4172-0592 \\ ${ }^{2}$ Centre for Biodiversity \& Biosecurity, School of Biological Sciences, University of Auckland, Auckland, New Zealand
}

The 'All genera of the world' series was announced by Zhang (2020) when Megataxa was launched. It aims to publish a full list of all genera (living and fossil) in a current consensus classification, including species richness, type species, and synonyms/homonyms (if any) for each genus. Original references for the generic names, type species, and nomenclatural changes should be checked and listed. This series, when completed, will provide a basis for a full inventory of life on Earth. It is an extension of a previous series of papers to the family level for animal diversity (Zhang 2011, 2013). The series invites individual taxonomists or a large team to submit small articles or large monographs for their taxa.

I am pleased to introduce here the first two lists/ papers in the series: one on the insect order Thysanoptera, with 1,270 available genus-group names, including 850 valid generic names, 65 of these fossils (Mound \& Hastenpflug-Vesmanis 2021); the other a related fossil order Lophioneurida with 22 generic names, including 18 valid generic names (Ulitzka 2021). These papers also provide examples for future contributions to the series. Our priority for the next few contributions will be on other hemipteroid groups. There are two routes: one by invitation by the chief editor, the other open submission. For the latter, we welcome potential authors to contact the chief editor first with a proposal.

To understand the scale of the series, I invited Rees $e t$ al. (2020) to provide an overview and estimates of known genera of the world from data in the Interim Register of Marine and Nonmarine Genera (IRMNG)). It is estimated that IRMNG includes 492,620 generic names and is about $96 \%$ complete (Rees et al. 2020); the papers in this series, therefore, will need to cover 513,146 generic names, plus more new ones described later. As the two papers here
(Mound \& Hastenpflug-Vesmanis 2021; Ulitzka 2021) include 1,292 generic names in 71 pages (or 18 per pages), we expect this series to require over 28,500 pages.

I thank Anne Austin (Manaaki Whenua-Landcare Research, Palmerston North) for reviewing the draft and comments.

\section{References}

Mound, L.A. \& Hastenpflug-Vesmanis, A. (2021) All genera of the world: Order Thysanoptera (Animalia: Arthropoda: Insecta). Megataxa, 6 (1), 2-69. https://doi.org/10.11646/megataxa.6.1.2

Rees, T., Vandepitte, L., Vanhoorne, B. \& Decock, W. (2020) All genera of the world: an overview and estimates based on the March 2020 release of the Interim Register of Marine and Nonmarine Genera (IRMNG). Megataxa, 1 (2), 123-142. https://doi.org/10.11646/megataxa.1.2.3

Ulitzka, M.R. (2021) All genera of the world: Order $\dagger$ Lophioneurida - fossil out-groups of Thripida (Animalia: Arthropoda: Insecta). Megataxa, 6 (1), 70-72. https://doi.org/10.11646/megataxa.6.1.3

Zhang, Z.-Q. (Ed.) (2011) Animal biodiversity: an outline of higher-level classification and survey of taxonomic richness. Zootaxa, 3148 (1), 1-237.

https://doi.org/10.11646/zootaxa.3148.1

Zhang, Z.-Q. (Ed.) (2013) Animal biodiversity: an outline of higher-level classification and survey of taxonomic richness (Addenda 2013). Zootaxa, 3703 (1), 1-82. https://doi.org/10.11646/zootaxa.3703.1

Zhang, Z.-Q. (2020) Megataxa for big science questions in taxonomy. Megataxa, 1 (1), 1-3. https://doi.org/10.11646/megataxa.1.1.1 